Collaboration on Radiation Driven Chemistry and Accelerator Operations

\title{
Cooperative Research and Development Agreement Final Report
}

\section{CRADA Number: FRA-2018-0017}

\section{Fermilab Technical Contact: Charles Cooper}

Summary Report

30 September 2019 


\section{NOTICE}

This report was prepared as an account of work sponsored by an agency of the United States government. Neither the United States government nor any agency thereof, nor any of their employees, makes any warranty, express or implied, or assumes any legal liability or responsibility for the accuracy, completeness, or usefulness of any information, apparatus, product, or process disclosed, or represents that its use would not infringe privately owned rights. Reference herein to any specific commercial product, process, or service by trade name, trademark, manufacturer, or otherwise does not necessarily constitute or imply its endorsement, recommendation, or favoring by the United States government or any agency thereof. The views and opinions of authors expressed herein do not necessarily state or reflect those of the United States government or any agency thereof.

Available electronically at http://www.osti.gov/bridge

Available for a processing fee to U.S. Department of Energy and its contractors, in paper, from:

U.S. Department of Energy Office of Scientific and Technical Information

P.O. Box 62

Oak Ridge, TN 37831-0062

phone: 865.576 .8401

fax: 865.576 .5728

email: mailto:reports@adonis.osti.gov

Available for sale to the public, in paper, from:

U.S. Department of Commerce

National Technical Information Service

5285 Port Royal Road

Springfield, VA 22161

phone: 800.553 .6847

fax: 703.605.6900

email: orders@ntis.fedworld.gov

online ordering: http://www.ntis.gov/ordering.htm 
In accordance with Requirements set forth in Article XII of the CRADA document, this document is the final CRADA report, including a list of Subject Inventions, to be forwarded to the Office of Science and Technical Information as part of the commitment to the public to demonstrate results of federally funded research.

CRADA number: $\quad$ FRA-2018-0017

CRADA Title: Collaboration on Radiation Driven Chemistry and Accelerator Operations

Parties to the Agreement: University of Notre Dame Du Lac and Fermi Research Alliance, LLC.

\section{Abstract of CRADA work:}

The Notre Dame Radiation Laboratory (NDRL) will contribute subject matter expertise to increase the Fermilab Illinois Accelerator Research (IARC) team's knowledge of radiation chemistry processes. NDRL will do this by offering guidance on what analytical equipment to use to measure the effects of electron beam treatment during and post treatment. NDRL will also offer guidance that will help further develop IARC applications. The application areas are not limited to, but may include chemistries in the energy generation, industrial and environmental sectors.

Fermi National Accelerator Laboratory's IARC team will contribute subject matter expertise on accelerator operations to help NDRL optimize operation of their Titan-Beta accelerator. The objective of NDRL is to optimize accelerator output, as well as the beam transport and focusing from the accelerator to several experimental beam ports. NDRL also wants to install and optimize a new subharmonic pre-buncher to be able to deliver sub-nanosecond timescale doses for the study of reaction kinetics decoupled from molecular diffusion.

\section{Summary of Research Results:}

This collaboration increased the knowledge of the IARC team's understanding on chemistry to develop radiation driven applications for the compact accelerator. In addition, the collaboration increased the ability of NDRL to efficiently operate their accelerator to allow them to better study effects of ionizing radiation on chemical systems.

\section{Related Reports, Publications, and Presentations:}

None 
Subject Inventions listing:

None

Report Date: 30 September 2019

Technical Contact at Fermilab: Charles Cooper

This document contains NO confidential, protectable or proprietary information. 